\title{
PEMBIAKAN NEMATODA PATOGEN SERANGGA (Rhabditida: Heterorhabditis DAN Steinernema) PADA MEDIA SEMI PADAT
}

\author{
Chaerani $^{1}$ \\ ${ }^{1}$ Balai Besar Penelitian dan Pengembangan Bioteknologi dan Sumber Daya Genetik Pertanian (BB-Biogen), \\ Jln. Tentara Pelajar 3A, Bogor 16111.E-mail: chaeran1@ yahoo.com
}

\begin{abstract}
In vitro culture of entomopathogenic nematodes (Rhabditida: Heterorhabditis and Steinernema) on semi solid media. Field application of entomopathogenic nematodes (EPN) is still hampered by inefficient mass production. The aim of this study was to compare three published in vitro media (medium Wouts, Bedding and Han) for mass propagation of three indigenous EPNs (Heterorhabditis indicus PLR2, H. indicus isolate 5, and Steinernema T96) and one commercial strain (S. carpocapsae \#25). The media were impregnated in shredded polyurethane sponge, pre-inoculated with symbiotic bacteria of each nematode and inoculated with the respective infective juveniles (IJs) of the nematode. Nematode yields at three weeks after nematode inoculation were inconsistent accross replications and experiments and generally not significantly influenced by the kind of media tested. Average yields showed that the highest IJ productions were obtained on medium Han for $H$. indicus PLR2 $\left(0,4 \times 10^{5} \mathrm{IJs} / \mathrm{g}\right.$ medium $)$ and for $S$. carpocapsae \#25 $\left(2.2 \times 10^{5} \mathrm{IJs} / \mathrm{g}\right.$ medium $)$, and on medium Wouts for $H$. indicus isolate 5 $\left(6.5 \times 10^{5} \mathrm{IJs} / \mathrm{g}\right.$ medium $)$ and Steinernema T96 $\left(1.5 \times 10^{5} \mathrm{IJs} / \mathrm{g}\right.$ medium $)$. The IJs' body were significantly shorter than those of in vivo propagated, which may impair the nematode pathogenicity. Modifications of the propagation technique and media formulation are needed to improve the quantity and quality of IJs.
\end{abstract}

Key words: entomopathogenic nematodes, mass propagation, in vitro media

\begin{abstract}
ABSTRAK
Pembiakan nematoda patogen serangga (Rhabditida: Heterorhabditis dan Steinernema) pada media semi padat. Aplikasi nematoda patogen serangga (NPS) di lapangan masih terkendala oleh produksi massalnya yang tidak efisien. Tujuan penelitian ini ialah untuk membandingkan tiga media in vitro (media Wouts, Bedding, dan Han) untuk perbanyakan massal tiga NPS lokal (Heterorhabditis indicus PLR2, H. indicus isolat 5, dan Steinernema T96) dan satu spesies komersial (S. carpocapsae \#25). Media diserapkan ke dalam potongan-potongan spons poliuretan, dipra-inokulasi dengan bakteri simbion dari masing-masing nematoda dan diinokulasi dengan juvenil infektif (JI) masing-masing nematoda. Populasi JI pada tiga minggu setelah inokulasi nematoda tidak konsisten antar ulangan maupun percobaan dan pada umumnya tidak dipengaruhi oleh macam media yang diuji. Rata-rata hasil menunjukkan bahwa produksi JI tertinggi diperoleh pada media Han untuk $H$. indicus PLR2 $\left(0,4 \times 10^{5} \mathrm{JI} / \mathrm{g}\right.$

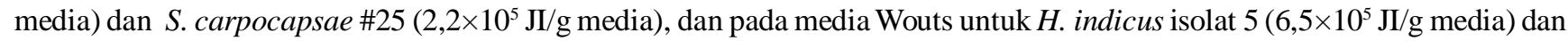
Steinernema T96 (1,5×10 JI/g media). Tubuh JI yang dihasilkan secara in vitro nyata lebih pendek dibandingkan dengan yang dihasilkan secara in vivo, yang diduga dapat menurunkan patogenisitas NPS. Modifikasi teknik perbanyakan dan formulasi media diperlukan untuk memperbaiki kuantitas dan kualitas JI.
\end{abstract}

Kata kunci: nematoda patogen serangga, pembiakan massal, media in vitro

\section{PENDAHULUAN}

Heterorhabditis dan Steinernema menularkan, secara berurutan, bakteri patogenik Photorhabdus spp. dan Xenorhabdus spp. ke dalam haemocoel serangga dan mampu memicu kematian serangga mulai 24 jam setelah menginvasi. Kompleks nematoda-bakteri ini merupakan pengendali hayati serangga yang aman terhadap organisme bukan sasaran dan telah digunakan secara komersial untuk mengendalikan seranggaserangga hama komoditas bernilai ekonomi tinggi di
Eropa dan Amerika Serikat (Ehlers, 1996). Di Indonesia nematoda patogen serangga (NPS) lokal telah banyak diisolasi (antara lain Griffin et al., 2000; Chaerani et al., 2007) dan diketahui efektif terhadap berbagai serangga hama penting di rumah kaca ataupun lapangan, antara lain terhadap kompleks penggerek batang padi (Fallon, 1998; Chaerani \& Nurbaeti, 2006, 2007), hama lanas ubijalar (Chaerani \& Waluyo, 2006), dan pengorok daun krisan (Yulensri et al., 2001).

Pemanfaatan NPS lokal secara luas di lapangan terkendala oleh produksi massalnya. Produksi massal 
secara in vivo mudah dilakukan tetapi tidak ekonomis untuk skala komersial sehingga perbanyakan pada media buatan sangat diperlukan untuk mengurangi luas ruangan pembiakan dan biaya tenaga kerja (Friedman, 1990). Pembiakan NPS pada media in vitro dicoba untuk pertama kali menggunakan media berbasis nabati ditambah dengan yeast extract tetapi hasilnya mengecewakan (Poinar, 1979). Terobosan nyata dalam pembiakan in vitro dilakukan oleh Bedding (1981) setelah diketahui bahwa NPS bersimbiosis mutualistik dengan bakteri untuk bereproduksi (Poinar \& Thomas, 1966). NPS berhasil dibiakkan pada media in vitro secara monoksenik, yaitu bersama-sama dengan bakteri simbionnya (Bedding, 1981). Media kaya protein dan lemak hewani dari organ-organ dalam babi, sapi, atau ayam diserapkan ke dalam spons poliuretan kemudian dimasukkan ke dalam botol erlenmeyer (Bedding, 1981) atau kantung plastik berkapasitas $5 \mathrm{~kg}$ (Bedding, 1984). Substrat ini disterilisasi dan selanjutnya dipra-inokulasi dengan bakteri simbion sehari atau dua hari sebelum diinokulasi dengan nematoda (Bedding, 1981, 1984). Teknologi pembiakan pada media semi padat cocok diterapkan di negara berkembang dimana tenaga kerja mudah didapatkan, tidak memerlukan investasi peralatan yang mahal, dan teknologinya mudah dikerjakan. Variasi sumber protein dan lemak hewani dari bagian organorgan dalam lainnya (Dunphy \& Webster, 1989; Han et al., 1993), bahkan nabati telah digunakan pada media in vitro (Wouts, 1981).

Penelitian ini bertujuan untuk mengetahui media yang sesuai untuk pembiakan massal NPS lokal dalam rangka memperluas pemanfaatan NPS lokal di lapangan. Tiga media semi padat formula Wouts (1981), Bedding (1981, 1984), dan Han et al. (1993) diuji untuk tujuan ini.

\section{METODE PENELITIAN}

Inokulum Nematoda. NPS yang digunakan dalam percobaan adalah $H$. indicus isolat PLR2 dan 5 yang diisolasi dari Pelabuhan Ratu, Jawa Barat (Chaerani et al., 2007), Steinernema isolat T96 yang diisolasi dari Waen, Ambon (Griffin et al., 2000), dan S. carpocapsae \#25 yang diperoleh dari contoh produk komersial Biosys Inc. (Amerika Serikat). Nematoda diperbanyak pada larva Tenebrio molitor (Coleoptera: Tenebrionidae) menggunakan metode inokulasi kertas saring pada cawan petri (Woodring \& Kaya, 1988). Juvenil infektif (JI) disterilisasi permukaan dengan 0,4\% Hyamine-10× (Sigma) selama 15 menit dan dibilas tiga kali dengan akuades steril sebelum digunakan sebagai inokulum (Woodring \& Kaya, 1988).
Inokulum Bakteri. Bakteri simbion diisolasi pada media selektif NBTA (20 g NB; 0,25 g bromothymol blue; $0,04 \mathrm{~g}$ triphenyl tetrazolium chloride, 11 akuades) dari hemolimfa larva T. molitor, yang diinokulasi dengan JI pada 24-48 jam sebelumnya (Woodring \& Kaya, 1988). Bakteri fase primer, yaitu yang berkoloni hijau kebiruan dikelilingi zona bening, diambil kemudian diperbanyak pada $100 \mathrm{ml}$ media NB dalam erlenmeyer $250 \mathrm{ml}$ selama 48 jam di atas orbital shaker pada kecepatan $170 \mathrm{rpm}$. Biakan disentrifugasi selama 15 menit pada kecepatan $3500 \mathrm{rpm}$ kemudian peletnya diresuspensi dalam larutan $\mathrm{NaCl} 0,5 \%$ steril. Konsentrasi sel bakteri dihitung menggunakan hemositometer.

Media Perlakuan. Tiga media in vitro dari Wouts (1981), Bedding (1984), dan Han et al. (1993), yang selanjutnya secara berurutan disebut sebagai media Wouts, media Bedding dan media Han, dibandingkan kesesuaiannya untuk memproduksi JI (Tabel 1). Media dicampurkan ke dalam potongan-potongan spons poliuretan $(1 \mathrm{~cm} \times 1 \mathrm{~cm})$ dengan perbandingan $10: 1$ atau $12: 1$ berdasarkan bobot (Tabel 1). Formulasi ini dimasukkan ke dalam botol kaca bekas selai (volume $300 \mathrm{ml}$ ) sebanyak 150-200 ml. Botol disumbat dengan kapas dan ditutup dengan kertas dan selanjutnya disterilisasi dalam otoklaf selama 1 jam pada suhu $121^{\circ} \mathrm{C}$ (1,5 atm). Media diinokulasi dengan $0,1 \mathrm{ml}$ bakteri fase primer (konsentrasi $0,6-150,0 \times 10^{10} \mathrm{CFU} / \mathrm{ml}$ larutan $\mathrm{NaOCl} 0,5 \%$ ) kemudian diinkubasi dalam keadaan gelap pada suhu ruangan. Setelah 48 jam media diinfestasi dengan $0,5 \mathrm{ml}$ akuades steril mengandung $0,5 \times 10^{4} \mathrm{JI} / \mathrm{ml}$ kemudian diinkubasi kembali.

Populasi JI diamati pada 7, 14 dan 21 hari setelah inokulasi (HSI) dari 5 sampel, masing-masing $1 \mathrm{~g}$ spons, yang kemudian direndam dalam air yang telah diketahui volumenya. Percobaan dilaksanakan secara terpisah untuk tiap nematoda karena bakteri simbion tiap nematoda diisolasi dalam waktu yang tidak bersamaan. Untuk setiap NPS terdapat enam ulangan untuk tiap perlakuan media dan untuk tiap ulangan terdapat satu botol biakan. Akan tetapi selama masa inkubasi terjadi kontaminasi pada biakan $H$. indicus PLR2, $H$. indicus isolat 5, dan S. carpocapsae \#25 oleh larva Drosophila sp. sehingga tersisa tiga ulangan yang dapat diamati. Percobaan diulang kembali untuk ketiga nematoda tersebut, masing-masing dengan tiga ulangan perlakuan media.

Pengukuran Morfometrik JI. Panjang tubuh JI pada 21 HSI diukur dari ujung anterior hingga posterior sedangkan lebarnya diukur pada bagian tubuh yang terlebar dengan menggunakan mikrometer di bawah 
Tabel 1. Komposisi media in vitro untuk perbanyakan Heterorhabditis dan Steinernema

\begin{tabular}{lcccc}
\hline \multirow{2}{*}{ Bahan } & Media & \multicolumn{2}{c}{ Media Bedding } & \multirow{2}{*}{ Media Han $^{\mathrm{a}}$} \\
\cline { 3 - 4 } & Wouts $^{\mathrm{a}}$ & Heterorhabditis & Steinernema & \\
\hline Yeast extract & 0,4 & 0,0 & 0,0 & 1,0 \\
Nutrient broth & 1,1 & 0,0 & 0,0 & 0,0 \\
Pepton & 0,0 & 0,0 & 0,0 & 1,0 \\
Minyak kedelai & 13,0 & 0,0 & 0,0 & 0,0 \\
Tepung kedelai & 18,0 & 0,0 & 0,0 & 15,0 \\
Usus ayam & 0,0 & $70,0^{\mathrm{b}}$ & $80,0^{\mathrm{b}}$ & 0,0 \\
Lemak sapi & 0,0 & $10,0^{\mathrm{b}}$ & 0,0 & 5,0 \\
Telur ayam & 0,0 & 0,0 & 0,0 & 20,0 \\
Akuades & 67,5 & $20,0^{\mathrm{b}}$ & $20,0^{\mathrm{b}}$ & 48,0 \\
\hline Spons : adonan media & $12: 1$ & $12: 1^{\mathrm{a}}$ & $12: 1^{\mathrm{a}}$ & $10: 1$ \\
\hline
\end{tabular}

${ }^{\mathrm{a}}$ perbandingan $\mathrm{b} / \mathrm{b}$

${ }^{\mathrm{b}}$ perbandingan $\mathrm{v} / \mathrm{v}$

mikroskop. Pengukuran dilakukan terhadap tiga dari keempat nematoda, yaitu $H$. indicus PLR2, $S$. carpocapsae \#25, dan Steinernema T96, yang masingmasing mewakili spesies yang berbeda. Ukuran tubuh ketiganya dibandingkan dengan ukuran tubuh JI hasil perbanyakan pada larva T. molitor.

Analisis Statistik. Percobaan dilaksanakan dalam Rancangan Acak Kelompok. Data populasi dan morfometrik JI dianalisis menggunakan prosedur GLM dari SPSS 12.0. Data populasi JI ditransformasi ke dalam $\log (Y+1)$ sebelum dianalisis untuk menstabilkan keragaman galat. Rata-rata populasi JI antar perlakuan dibedakan menggunakan uji DMRT pada taraf $P=0,05$. Data populasi JI H. indicus PLR2, $H$. indicus isolat 5, dan $S$. carpocapsae \#25 diperoleh dari dua percobaan. Analisis statistik dilakukan secara terpisah untuk tiap percobaan jika hasil analisis data gabungan dua percobaan untuk ketiga NPS ini menunjukkan pengaruh repetisi percobaan yang signifikan. Rata-rata populasi JI untuk masing-masing perlakuan media dari dua percobaan yang dianalisis statistik secara terpisah dihitung dengan cara memboboti rata-rata populasi JI dari tiap perlakuan media pada tiap percobaan dengan nilai keragamannya (=rata-rata terboboti [weighted mean], Kearsey \& Pooni, 1996).

\section{HASIL DAN PEMBAHASAN}

Produksi JI. Media yang diinokulasi dengan Photorhabdus berubah warna menjadi merah kecoklatan setelah 24-48 jam, sedangkan yang diinokulasi dengan Xenorhabdus spp. tidak memperlihatkan perubahan warna. JI keluar dari pori-pori spons dan menempel pada dinding bagian dalam botol (Gambar 1).
Populasi JI keempat nematoda pada hari ke-21 pada ketiga media menunjukkan kisaran yang luas, yang menandakan adanya variasi tingkat produksi antar ulangan dan percobaan (Tabel 2). Analisis data gabungan dua percobaan menunjukkan pengaruh repetisi percobaan yang signifikan terhadap populasi JI $H$. indicus isolat PLR2 dan isolat $5(P<0,05)$, sehingga data masing-masing percobaan dianalisis secara terpisah untuk masing-masing isolat. Sementara itu repetisi percobaan tidak berpengaruh nyata terhadap produksi JI $S$. carpocapsae \#25 $(P>0,05)$, sehingga data kedua percobaan digabung dan dianalisis bersama.

Perlakuan media tidak memengaruhi produksi JI H. indicus PLR2, S. carpocapsae \#25, dan Steinernema T96 $(P>0,05)$, tetapi berpengaruh terhadap produksi JI $H$. indicus isolat 5 hanya pada Percobaan 2 $(P<0,05)$. Berdasarkan rata-rata terboboti formula media Han menghasilkan $2,2 \times 10^{5} \mathrm{JI} H$. indicus PLR2 dan $0,4 \times 10^{5} \mathrm{JI} S$. carpocapsae \#25 per g media, sedangkan formula media Wouts menghasilkan $6,5 \times 10^{5} \mathrm{JI} H$. indicus isolat 5 dan $1,5 \times 10^{5} \mathrm{JI}$ Steinernema T96 per $\mathrm{g}$ media.

Pengamatan mingguan menunjukkan bahwa populasi JI $H$. indicus isolat 5 dan $S$. carpocapsae \#25 pada ketiga media semakin meningkat dengan meningkatnya masa inkubasi (Gambar 2). Populasi JI $H$. indicus PLR2 terus meningkat pada media Han, sedangkan pada kedua media lainnya berfluktuasi. Sementara itu populasi JI Steinernema T96 pada ketiga media befluktuasi selama masa inkubasi. Pada media Han produksi JI T96 tertinggi $\left(1,6 \times 10^{5}\right.$ ekor/g media) terjadi dalam waktu hanya 2 minggu sehingga JI dapat dipanen seminggu lebih awal jika diperbanyak pada media ini. 


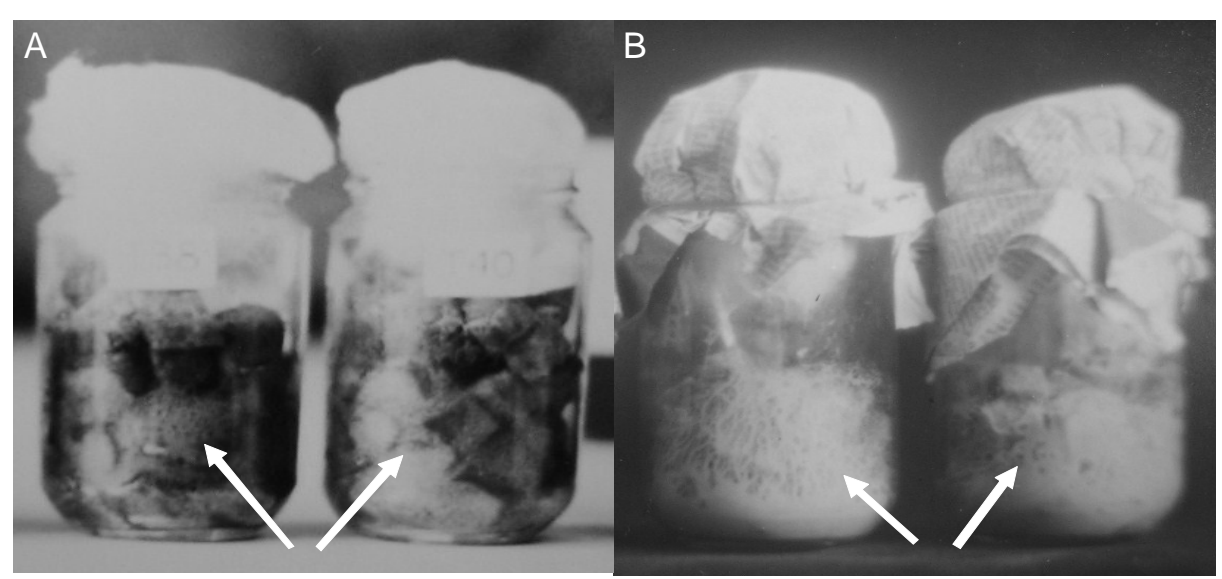

Gambar 1. Biakan H. indicus (A) dan Steinernema sp. (B) pada media in vitro Bedding $(1981,1984)$ yang diformulasi dalam spons poliuretan. Juvenil infektif yang siap dipanen terlihat sebagai jejaring massa putih menempel pada dinding bagian dalam botol (ditunjukkan oleh anak panah)
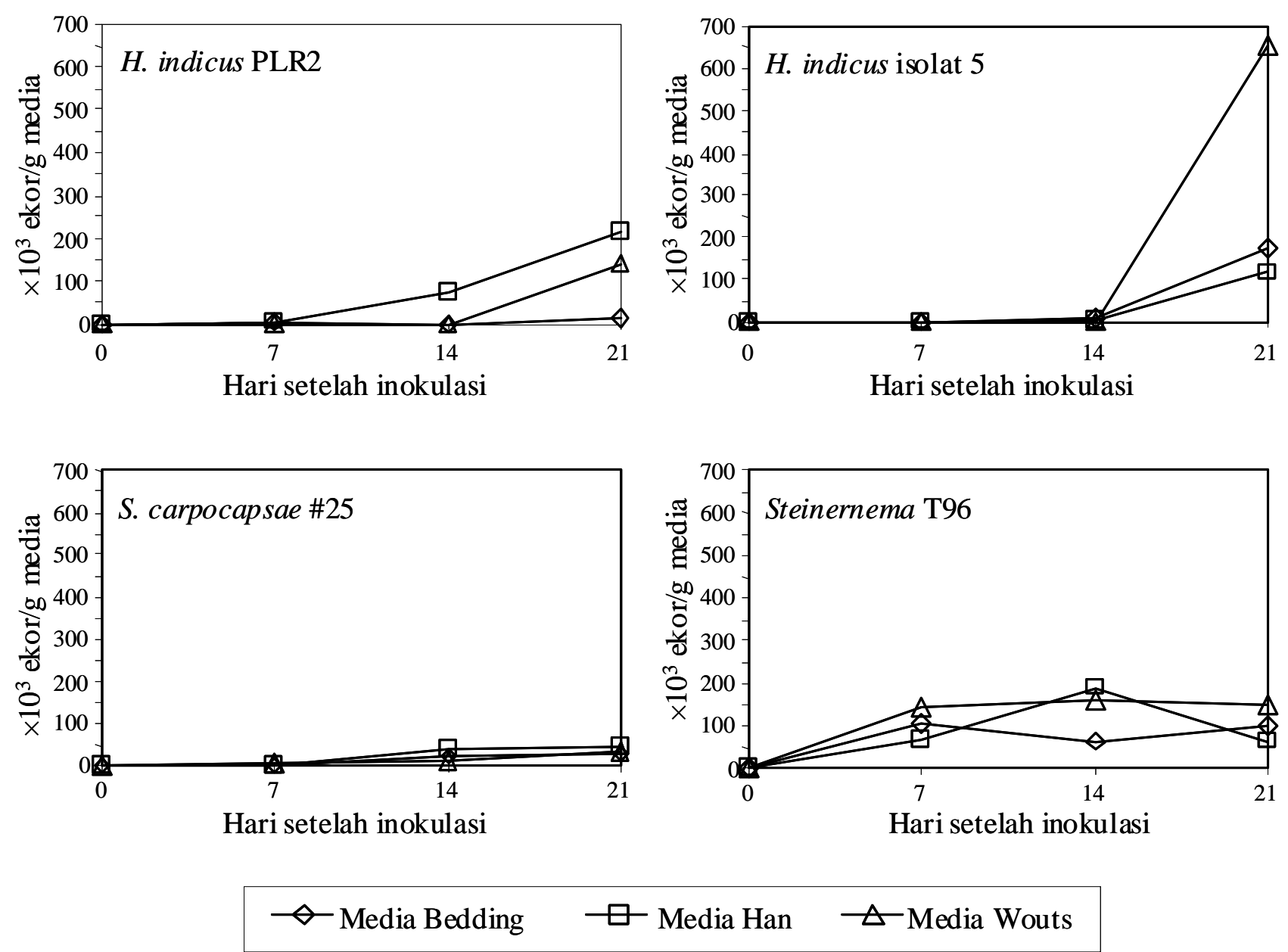

Gambar 2. Pertumbuhan populasi juvenil infektif Heterorhabditis dan Steinernema pada tiga media in vitro semi padat yang diformulasi dalam spons 
Tabel 2. Produksi juvenil infektif Heterorhabditis dan Steinernema (ekor/g media) a pada tiga media in vitro yang diformulasi dalam spons poliuretan

\begin{tabular}{|c|c|c|c|c|}
\hline Media & Percobaan $1^{\mathrm{b}, \mathrm{c}}$ & Percobaan $2^{\mathrm{b}, \mathrm{c}}$ & Percobaan 1 dan 2 & $\begin{array}{l}\text { Rata-rata } \\
\text { terboboti } \\
\end{array}$ \\
\hline \multicolumn{5}{|c|}{ H. indicus PLR2 $\left(\mathrm{x} 10^{4} \mathrm{JI} / \mathrm{g} \text { Media }\right)^{\mathrm{e}}$} \\
\hline Bedding & $0.0(0.0-5.0)$ & $3.1(0.1-18.7)$ & - & 1.4 \\
\hline Wouts & $0.2(0.0-0.3)$ & $22.5(18.6-27.3)$ & - & 14.2 \\
\hline Han & $2.9(2.3-27.5)$ & $27.3(16.0-45.3)$ & - & 21.5 \\
\hline Nilai $P$ media & 0.678 & 0.439 & - & \\
\hline Nilai $P$ percobaan & - & - & 0.008 & \\
\hline \multicolumn{5}{|c|}{ H. indicus isolat $5\left(\times 10^{4} \mathrm{JI} / \mathrm{g} \mathrm{Media}\right)^{\mathrm{e}}$} \\
\hline Bedding & $0.0(0.0-1.4)$ & $26.2(8.4-47.1) \mathrm{ab}$ & - & 17.2 \\
\hline Wouts & $0.0(0.0)$ & $65.0(29.2-125.4) \mathrm{a}$ & - & 65.0 \\
\hline Han & $0.0(0.0-2.3)$ & $12.0(9.2-14.6) \mathrm{a}$ & - & 11.9 \\
\hline Nilai $P$ media & 0.438 & 0.031 & - & \\
\hline Nilai $P$ percobaan & - & - & 0.000 & \\
\hline \multicolumn{5}{|c|}{ S. carpocapsae \#25 $\left(\times 10^{4} \mathrm{JI} / \mathrm{g} \text { Media }\right)^{\mathrm{e}}$} \\
\hline Bedding & $0.8(0.0-93.4)$ & $14.6(1.2-69.4)$ & 2.8 & - \\
\hline Wouts & $1.2(0.0-16.5)$ & $20.8(7.7-68.5)$ & 3.0 & - \\
\hline Han & $1.5(0.0-30.6)$ & $85.6(52.9-138.5)$ & 4.1 & - \\
\hline Nilai $P$ media & 0.958 & 0.564 & 0.896 & - \\
\hline Nilai $P$ percobaan & - & - & 0.073 & - \\
\hline \multicolumn{5}{|c|}{ Steinernema $\mathrm{T} 96\left(\times 10^{4} \mathrm{JI} / \mathrm{g} \text { Media }\right)^{\mathrm{f}}$} \\
\hline Bedding & $9.9(5.5-15.1)$ & - & - & - \\
\hline Wouts & $14.7(8.5-25.9)$ & - & - & - \\
\hline Han & $6.1(2.9-15.9)$ & - & - & - \\
\hline Nilai $P$ media & 0.068 & - & - & - \\
\hline
\end{tabular}

${ }^{\text {a }}$ Transformasi balik dari $\log (Y+1)$.

${ }^{\mathrm{b}}$ Angka-ang ka dalam kurung menyatakan kisaran produksi.

${ }^{\mathrm{c}}$ Angka sekolom yang diikuti oleh hur uf yang sama tidak berbeda nyata menurut uji DMRT $(P=0,05)$.

${ }^{\mathrm{d}}$ Rata-rata dari dua percobaan yang dianalisis statistik secara terpisah, dihitung menggunakan rumus:

$?\left(Y_{i} / s_{i}^{2}\right) / ?\left(1 / s_{i}^{2}\right)$, dimana $Y$ adalah rata-rata populasi JI dan $s^{2}$ adalah keragaman.

${ }^{\mathrm{e}} \mathrm{R}$ ata-rata dari tiga ulangan.

${ }^{\mathrm{f}}$ Rata-rata dari enam ulangan. 
Rata-rata hasil JI pada media Bedding dan Han tersebut pada umumnya lebih rendah daripada yang dilaporkan oleh peneliti-peneliti sebelumnya untuk berbagai spesies NPS. Untuk $H$. indicus rata-rata hasil ini bahkan masih lebih rendah dari hasil perbanyakan pada serangga (Chaerani, 2006, tidak dipublikasikan).

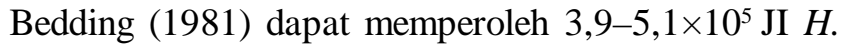
bacteriophora; $7,0 \times 10^{5}$ Heterorhabditis isolat Darwin; $5,4 \times 10^{5} \mathrm{JI} S$. carpocapsae; $4,1 \times 10^{5} \mathrm{JI} S$. feltiae; dan $1,1 \times 10^{5}$ JI $S$. glaseri per g media. Han et al. (1993) berhasil mendapatkan $7,6 \times 10^{5} \mathrm{JI}$ isolat $S$. carpocapsae komersial (Agriotos) per g media, yang 19 kali lebih banyak daripada rata-rata dua percobaan yang dicapai pada penelitian ini untuk spesies yang sama. Akan tetapi hal ini tidak selalu konsisten, misalnya pada Percobaan 2 hasil $S$. carpocapsae \#25 lebih tinggi $\left(8,6 \times 10^{5} \mathrm{JI} / \mathrm{g}\right.$ media) daripada yang diperoleh Han et al. (1993). Sementara itu hasil JI $H$. indicus isolat 5 dapat mencapai 6 kali lebih banyak dibandingkan dengan yang diperoleh Wouts (1981) untuk H. bacteriophora pada media yang sama.

Salah satu penyebab inkonsistensi tingkat produksi JI antarulangan dan percobaan adalah sistem pembiakan monoksenik yang belum bebas dari mikroorganisme kontaminan yang tidak bersimbiosis dengan NPS. Metode sterilisasi permukaan JI tidak dapat menghilangkan mikroorganisme non-simbiotik yang mungkin terikut dalam saluran pencernaan JI (Lunau et al., 1993; Boemare et al., 1996). Ketika JI diinokulasikan pada media, mikroorganisme nonsimbiotik juga tertransmisikan pada media sehingga mengakibatkan terjadinya polikseniksasi, dimana lebih dari satu mikroorganisme berkembang biak (Lunau et al., 1993; Boemare et al., 1996). Mikroorganisme nonsimbiotik ini dapat bersaing dengan bakteri simbion untuk nutrisi sehingga berakibat pada penurunan reproduksi NPS. Penggunaan inokulum stadia J-1 aksenik (tanpa bakteri simbion) untuk perbanyakan Steinernema dan stadia J-1 yang ditumbuhkan bersama-sama bakteri simbion untuk perbanyakan Heterorhabditis dapat menghindari poliksenisasi media pembiakan (Lunau et al., 1993).

Kebanyakan formula media in vitro mengandung komponen nutrisi asal hewan maupun tumbuhan sehingga kurang mirip dengan komposisi nutrisi pada tubuh serangga (Wouts, 1981; Bedding 1981, 1984; Friedman, 1990; Han et al. 1993; Surrey \& Davies, 1996; Yoo et al., 2000). Penambahan komponen yang mirip dengan yang ada pada tubuh serangga atau komponen yang dapat menunjang sintesis metabolit yang serupa dengan yang ada dalam tubuh serangga inang alami NPS dapat meningkatkan pertumbuhan NPS dengan kualitas yang sebanding dengan yang dihasilkan secara in vivo. S. kushidai, satu spesies endemik di Jepang yang sulit dibiakkan pada beberapa media in vitro yang biasa digunakan, dapat ditingkatkan produksinya dari $<2 \times 10^{5}$ menjadi $>5 \times 10^{5} / \mathrm{ml} \mathrm{jika} \mathrm{media}$ ditambah komponen berasal dari serangga berupa tepung kepompong ulat sutera (Ogura \& Haraguchi, 1994). Lipida merupakan sumber energi terpenting nematoda karena $60 \%$ dari total energinya diperoleh dari metabolisme lipida (Lee \& Atkinson, 1977; Selvan et al., 1993; Yoo et al., 2000). Akan tetapi karena kemampuannya terbatas dalam mensintesis lipida maka NPS mengandalkan bakteri untuk mendapatkan lipida esensial. Profil lipida pada tubuh NPS mirip dengan profil lipida seluler bakteri, yang diketahui juga mirip dengan komposisi lipida yang ada pada media tumbuhnya (Hatab \& Gaugler, 1997). Sumber lipida kaya asam oleat seperti minyak zaitun atau sumber lipida kaya sterol seperti ekstrak hati hewan dapat meningkatkan kadar total lipid seluler bakteri (Hatab \& Gaugler, 1999). Yoo et al. (2000) juga melaporkan bahwa penambahan minyak zaitun dan minyak yang kaya asam lemak jenuh lainnya seperti minyak kanola dapat menghasilkan pertumbuhan H. bacteriophora secara optimal sehingga populasi JI telah mencapai $2,8 \times 10^{5} \mathrm{ekor} / \mathrm{ml}$ hanya dalam waktu 8 hari.

Morfometrik JI. Perlakuan media perbanyakan berpengaruh sangat nyata terhadap ukuran tubuh JI $H$. indicus PLR2, S. carpocapsae \#25, dan Steinernema T96 $(P<0,05)$. Panjang dan lebar tubuh JI kedua spesies Steinernema yang dihasilkan pada media in vitro lebih pendek daripada yang dihasilkan secara in vivo pada larva T. molitor (Tabel 3). Sementara itu JI H. indicus PLR2 yang dihasilkan pada media in vitro tubuhnya lebih pendek, tetapi lebih lebar atau setara dengan yang dihasilkan secara in vivo. Nguyen \& Smart (1995) juga melaporkan bahwa morfometrik JI Steinernema spp. yang dihasilkan pada media in vitro lebih pendek daripada yang dihasilkan secara in vivo. Abnormalitas ukuran tubuh ini menunjukkan bahwa media in vitro miskin unsur esensial untuk pertumbuhan nematoda (Nguyen \& Smart, 1995). Dengan ukuran tubuh yang abnormal diduga ketegaran dan kebugaran JI untuk mencari dan menginfeksi serangga akan berkurang. 
Tabel 3. Ukuran tubuh juvenil infektif Heterorhabditis dan Steinernema hasil perbanyakan pada tiga media in vitro yang diformulasi dalam spons poliuretan ${ }^{\mathrm{a}, \mathrm{b}}$

\begin{tabular}{|c|c|c|c|c|c|c|c|c|c|}
\hline \multirow{2}{*}{ Media } & \multicolumn{3}{|c|}{ H. indicus PLR2 } & \multicolumn{3}{|c|}{ S. carpocapsae \# 25} & \multicolumn{3}{|c|}{ Steinernema T96 } \\
\hline & $n$ & $\mathrm{P}(\mu \mathrm{m})^{\mathrm{c}}$ & $\mathrm{L}(\mu \mathrm{m})^{\mathrm{c}}$ & $n$ & $\mathrm{P}(\mu \mathrm{m})$ & $\mathrm{L}(\mu \mathrm{m})$ & $n$ & $\mathrm{P}(\mu \mathrm{m})$ & $\mathrm{L}(\mu \mathrm{m})$ \\
\hline Wouts & 30 & $440,8 \mathrm{~b}$ & $19,9 \mathrm{~b}$ & 7 & $364,3 \mathrm{c}$ & $22,1 \mathrm{c}$ & 60 & $747,1 \mathrm{~b}$ & $35,1 \mathrm{~b}$ \\
\hline Bedding & 30 & $444,2 \mathrm{~b}$ & $21,9 \mathrm{a}$ & 30 & $495,0 \mathrm{~b}$ & $25,5 \mathrm{~b}$ & 60 & $765,0 \mathrm{~b}$ & $36,9 \mathrm{~b}$ \\
\hline Han & 30 & $429,2 \mathrm{~b}$ & $18,7 \mathrm{c}$ & 18 & $441,0 \mathrm{c}$ & $22,3 \mathrm{c}$ & 60 & $769,2 \mathrm{~b}$ & $35,2 \mathrm{~b}$ \\
\hline Tenebrio molitor & 30 & 521,2 a & $19,0 \mathrm{bc}$ & 30 & $578,7 \mathrm{a}$ & $29,8 \mathrm{a}$ & 10 & $982,5 \mathrm{a}$ & $42,4 \mathrm{a}$ \\
\hline Nilai $P$ & & 0,000 & 0,000 & & 0,000 & 0,000 & & 0,000 & 0,000 \\
\hline
\end{tabular}

${ }^{\mathrm{a} D i u k u r}$ pada hari ke-21 setelah inokulasi JI.

${ }^{\mathrm{b}}$ Angka sekolom yang diikuti huruf yang sama tidak berbeda nya ta menurut uji DMRT $(P=0,05)$.

${ }^{\mathrm{c}} \mathrm{P}=$ panjang, $\mathrm{L}=$ leb ar.

\section{SIMPULAN}

Produksi JI $H$. indicus isolat PLR2 dan $5, S$. carpocapsae \#25 dan Steinernema T96 tidak dipengaruhi oleh perlakuan media in vitro. Hasil JI secara umum tidak konsisten dan masih rendah, dengan hasil tertinggi untuk $H$. indicus PLR2 dan $S$. carpocapsae \#25 diperoleh pada media formula Han (berturut-turut $2,2 \times 10^{5}$ dan $0,4 \times 10^{5} \mathrm{JI} / \mathrm{g}$ media), sedangkan untuk $H$. indicus isolat 5 dan Steinernema T96 diperoleh pada media formula Wouts (berturut-turut $6,5 \times 10^{5}$ dan $1,5 \times 10^{5} \mathrm{JJ} / \mathrm{g}$ media). Tubuh JI nematoda nyata lebih pendek dibandingkan dengan yang dihasilkan pada larva $T$. molitor.

Peningkatan hasil JI diharapkan dapat dilakukan melalui 1) penggunaan inokulum juvenil aksenik, dan 2) modifikasi formula media dengan penambahan komponen-komponen yang serupa dengan yang terkandung pada hemolimfa serangga atau komponen yang dapat menunjang sintesis metabolit esensial yang diperlukan untuk pertumbuhan bakteri simbion dan NPS.

\section{SANWACANA}

Penghargaan yang sebesar-besarnya penulis sampaikan kepada Sdr. Atang (alm.), Sujatmo, dan Yusuf Habibie atas bantuan di laboratorium dan kepada para penelaah atas saran dan koreksi yang membangun. Penelitian didanai APBN dengan nomor proyek 01.6320.C.

\section{DAFTAR PUSTAKA}

Bedding RA. 1981. Low cost in vitro mass production of Neoaplectana and Heterorhabditis species (Nematoda) for field control of insect pests. Nematologica 27: 109-114.

Bedding RA. 1984. Large scale production, storage and transport of the insect-parasitic nematodes Neoaplectana spp. and Heterorhabditis spp. Ann. Appl. Biol. 104: 117-120.

Boemare N, Laumond C \& Mauleon H. 1996. The entomopathogenic nematode-bacterium complex: biology, life cycle and vertebrate safety. Biocont. Sci. Tech. 6: 333-345.

Chaerani \& Nurbaeti B. 2006. Efektivitas nematoda patogenik serangga (Rhabditida: Steinernema dan Heterorhabditis) terhadap penggerek batang padi putih (Scirpophaga innotata). J. Perlind. Tan. Ind. 12(2): 92-103.

Chaerani \& Nurbaeti B. 2007. Uji efektivitas nematoda entomopatogen (Rhabditida: Steinernema dan Heterorhabditis) sebagai musuh alami nonendemik penggerek batang padi kuning (Scirpophaga incertulas). JHPTT (2): 71-19.

Chaerani \& Waluyo. 2006. Pencarian nematoda patogenik serangga (Steinernema dan Heterorhabditis) yang efektif untuk pengendalian hama lanas (Cylas formicarius) ubi jalar. Widyariset 9(3): 19-28. 
Chaerani, Suryadi Y, Priyatno TP, Koswanudin D, Rahmat U, Sujatmo, Yusuf \& Griffin CT. 2007. Isolasi nematoda patogen serangga Steinernema dan Heterorhabditis. JHPTT 7(1): 1-9.

Dunphy GB \& Webster JM. 1989. The monoxenic culture of Neoaplectana carpocapsae DD 136 and Heterorhabditis heliothidis. Rev. Nematol. 12: 113-123.

Ehlers RU. 1996. Current and future use of nematodes in biocontrol: practice and commercial aspects with regard to regularoty policy issues. Biocont. Sci. Tech. 6: 303-316.

Fallon DF. 1998. The use of indigenous entomopathogenic nematodes Heterorhabditis indica and Steinernema spp. to control rice stem borer in West Java, Indonesia. Ph.D. thesis National University of Ireland.

Friedman MJ. 1990. Commercial production and development. Pages 153-171 in: Gaugler, R. \& Kaya HK, eds. Entomopathogenic Nematodes in Biological Control. CRC Press. Boca Raton, Ann Arbor, Boston.

Griffin CT, Chaerani R, Fallon D, Reid AP \& Downes MJ. 2000. Occurrence and distribution of the entomopathogenic nematodes Steinernema spp. and Heterorhabditis indica in Indonesia. $J$. Helminthol. 74: 143-150.

Han R, Cao L \& Liu X. 1993. Effects of inoculum size, temperature and time on in vitro production of Steinernema carpocapsae Agriotos. Nematologica 39: 366-375.

Hatab AM \& Gaugler R. 1997. Growth-mediated variations in fatty acids of Xenorhabdus spp. J. Appl. Microbiol. 82: 351-358.

Hatab AM \& Gaugler R. 1999. Lipids of in vivo and in vitro cultured H. bacteriophora. Biol. Cont. 15: 113-118.

Kearsey MJ \& Pooni HS. 1996. The Genetical Analysis of Quantitative Traits. Chapman \& Hall. London.
Lee DL \& Atkinson HJ. 1977. Physiology of Nematodes. Columbia University Press, New York.

Lunau S, Stoessel S, Schmidt-Peisker AJ \& Ehlers RU. 1993. Establishment of monoxenic inocula for scaling up in vitro culture of the entomopathogenis nematodes Steinernema spp. and Heterorhabditis spp. Nematologica 39:385-399.

Nguyen KB \& Smart Jr GC. 1995. Morphometrics of infective juveniles of Steinernema spp. and Heterorhabditis bacteriophora (Nemata: Rhabditida). J. Nematol. 27:206-212.

Ogura N \& Haraguchi N. 1994. Artificial media for xenic culture of Steinernema kushidai (Nematoda: Steinernematidae). Nematologica 40: 613-616.

Poinar Jr GO. 1979. Nematodes for biological control of insects. CRC Press, Florida.

Poinar Jr GO \& Thomas GM. 1966. Significance of Achromobacter nematophilus Poinar and Thomas (Achromobacteriaceae: Eubacteriales) in the development of the nematode, DD-136 (Neoaplectana sp., Steinernematidae). Parasitol. 56: 385-390.

Selvan S, Gaugler R \& Lewis EE. 1993. Biochemical energy reserves of entomopathogenic nematodes. J. Parasitol. 79: 167-172.

Surrey MR \& Davies RJ. 1996. Pilot-scale liquid culture and harvesting of an entomopathogenic nematode, Heterorhabditis bacteriophora. J. Invertebr. Pathol. 67: 92-99.

Woodring JL \& Kaya HK. 1988. Steinernematid and Heterorhabditid nematodes: a handbook of biology and techniques. Southern Cooperative Series Bulletin 331, Arkansas Agricultural Experiment Station, Fayetteville, Arkansas.

Wouts WM 1981. Mass production of the entomogenous nematode Heterorhabditis heliothidis (Nematoda: Heterorhabditidae) on artificial media. J. Nematol. 13: 467-469. 
Yoo SK, Brown I \& Gaugler R. 2000. Liquid media development for Heterorhabditis bacteriophora: lipid source and concentration. Appl. Microbiol. Biotech. 54: 759-763.
Yulensri, Santoso T, Rauf A \& Chaerani. 2001. UJi keefektifan nematoda entomopatogen Heterorhabditis indicus dan Steinernema riobravis terhadap hama pengorok daun Liriomyza huidobrensis (Blanchard) (Diptera: Agromyzidae). Simposium Pengendalian Hayati Serangga, Sukamandi, 14-15 Maret 2001. 